\title{
ANALISIS PERANGKAT PEMBELAJARAN MATEMATIKA PADA MASA PANDEMI COVID-19 DI SMP NEGERI 34 BANDAR LAMPUNG
}

\author{
Nanang Supriadi ${ }^{1}$, Dona Dinda Pratiwi ${ }^{2}$, Indri Yulianti ${ }^{3}$ \\ ${ }^{1}$ Universitas Islam Negeri Raden Intan Lampung, J1 Endro Suratmin, Sukarame, Lampung 35131, Indonesia \\ Email: indriyulia287@gmail.com
}

\begin{abstract}
Abstrak
Penelitian ini bertujuan untuk menganalisis perangkat pembelajaran pada masa pandemi Covid-19. Penelitian ini menggunakan pendekatan kualitatif dengan jenis penelitian deskriptif. Teknik pengumpulan data dilakukan adalah dengan metode observasi, wawancara, angket, dan dokumentasi. Waka kurikulum, 1 guru matematika dan 3 peserta didik kelas VII F SMP Negeri 34 Bandar Lampung adalah subjek penelitian. Proses analisis data pada penelitian ini meliputi reduksi data, penyajian data, dan penarikan kesimpulan. Menguji keabsahan data dengan menggunakan triangulasi tekhnik yaitu membandingkan hasil pengumpulan data observasi, wawancara, angket dan dokumentasi dari berbagai teknik pengumpulan data yang berbeda tersebut bertujuan untuk mendapatkan data dari sumber yang sama. Proses analisis data pada penelitian ini meliputi reduksi data, penyajian data, dan penarikan kesimpulan. Hasil penelitian menunjukkan bahwa proses dan persiapan guru dalam mempersiapkan perangkat pembelajaran pada masa pandemi Covid-19 sudah dalam kategori baik dan layak digunakan pada penmbelajaran daring. Hal tersebut dilihat dari hasil analisissilabus sebesar $76 \%$ dengan kategori baik, penilaian RPP sebesar 75\% dengan kategori baik, penilaian LKS sebesar 70\% dengan kategori baik, penilaianmedia pembelajaran sebesar 75\% dengan kategori baik dan penilaian model pembelajaran sebesar $70 \%$ dengan ketegori baik. Ketersediaan sarana dan prasarana dalam pembelajaran daring di sekolah sudah terpenuhi, baik dari segi guru maupun peserta didik. Kendala dalam pelaksanaan pembelajaran daring ini yaitu tidak stabilnya jaringan internet dan terkadang mengalami kesulitan dalam memahami materi pembelajaran.
\end{abstract}

Kata Kunci: Analisis, Perangkat Pembelajaran matematika, Pandemi Covid-19

\begin{abstract}
The research was carried out with the aim of analyzing learning devices during the Covid-19 pandemic. The specific objective to be achieved through this research is to describe the results of the analysis of the syllabus, lesson plans, worksheets, learning media and learning models. This study uses a qualitative approach with a descriptive type of research. The data collection technique was carried out by means of observation, interviews, questionnaires, and documentation. The research subjects in this study were the waka of the curriculum, 1 mathematics teacher and 3 students of class VII F at SMP Negeri 34 Bandar Lampung. The process of data analysis in this study includes data reduction, data presentation, and drawing conclusions. Testing the validity of the data by using technical triangulation, namely comparing the results of collecting data from observations, interviews, questionnaires and documentation from various different data collection techniques aimed at obtaining data from the same source. The process of data analysis in this study includes data reduction, data presentation, and drawing conclusions. The results showed that the process and preparation of teachers in preparing learning tools during the Covid-19 pandemic was in a good category and suitable for use in online learning. This can be seen from the results of the syllabus analysis of $76 \%$ in the good category, the RPP assessment by $75 \%$ in the good category, the LKS assessment by $70 \%$ in the good category, the assessment of learning media by $75 \%$ in the good category and the assessment of the learning model by $70 \%$ in the good category good. The availability of facilities and infrastructure in online learning in schools has been fulfilled, both in terms of teachers and students. Constraints in the implementation of online learning are the unstable internet network and sometimes having difficulty understanding learning materials.
\end{abstract}

Keywords: Analysis, Learning Tools, Covid-19 Pandemic 


\section{PENDAHULUAN}

Belakangan ini dunia sedang dilanda kesedihan mendalam akibat mewabahnya Coronavirus Disease (Covid-19) yang hampir melanda diseluruh nusantara (Sadikin et al., 2020). Covid-19 sendiri merupakan Coronavirus jenis baru yang ditemukan di Wuhan, China pada tahun 2019, penyakit ini adalah penyakit yang menyerang sistem pernafasan. Penyebaran virus Corona dapat terjadi melalui kontak antara satu individu dengan individu lainnya. WHO telah menetapkan wabah virus Covid-19 sebagai darurat kesehatan pada 30 Januari 2020. Darurat kesehatan masyarakat yang menjadi perhatian secara Internasional karena menyebabkan risiko tinggi untuk negara yang belum meliliki pelayanan kesehatan yang memadai atau masih dalam pelayanan kesehatan yang rentan (Firman, 2020).

Pandemi Covid-19 tidak hanya berpengaruh pada aspek kehidupan, tetapi juga pada aspek kesehatan, dan juga berpengaruh pada dunia pendidikan. Penutupan luas sekolah, madrasah, universitas dan pondok pesantren adalah salah satu dampak dari pandemi covid-19 pada aspek pendidikan. Kebijakan baru terhadap dunia pendidikan adalah merubah pembelajaran tatap muka menjadi pembelajaran dari rumah. Kementerian Pendidikan dan Kebudayaan (Kemendikbud) telah mengambil kebijakan sebagai panduan dalam menghadapi penyakit tersebut di tingkat satuan pendidikan (Rusdiana et al., 2020) sehubungan dengan perkembangan tersebut. Karena adanya pandemi covid-19 dunia pendidikan seolah dipaksa untuk merubah dari sistem pembelajaran tradisional ke sistem yang modern.

Berdasarkan kondisi seperti saat ini, telah dikeluarkan surat edaran Nomor 4 tahun 2020 pada tanggal 24 maret 2020 oleh Menteri Pendidikan dan Kebudayaan Republik Indonesia, Nadiem Anwar Makarim yang berisi tentang Pelaksanaan Kebijakan Pendidikan dalam masa darurat penyebaran Covid-19. Surat edaran menjelaskan bahwa proses pembelajaran dilaksanakan di rumah melalui. Merubah proses pembelajaran dari pembelajaran tatap muka menjadi pembelajaran jarak jauh adalah pencegahan penyebaran virus Covid-19 dapat dilakukan dengan salah satunya. Pembelajaran yang dilakukan secara daring memerlukan perangkat untuk pelaksanaan pembelajaran yaitu dengan memanfaatkan teknologi informasi (Sabaruddin et al., 2020).

Pembelajaran daring menjadi pembelajaran yang kurang efektif karena masih banyak terdapat hambatan-hambatan yang terdapat pada guru dan siswa. Berasarkan analisis perkembangan teknologi saat ini masyarakat Indonesia harusnya bisa mengimbangi perubahan teknologi yang begitu cepat. Seharusnya perubahan tersebut mampu menciptakan proses pembelajaran berlangsung tanpa batasan ruang maupun waktu serta harus berinovasi dalam rangka menyesuaikan pengetahuan dan kemampuan diera industri 4.0 (Wiryanto, 2020).

Permasalahan yang muncul masih banyak dunia pendidikan yang asing dengan pembelajaran jarak jauh karena lembaga pendidikan masih jarang menerapkan pembelajaran jarak jauh. Pembelajaran dalam jaringan sangat mempengaruhi prestasi atau keberhasilan siswa dalam pembelajaran. Selama implementasinya sering kali menemukan hambatan atau ketidaksesuaian dengan pembelajaran yang seharusnya (Herliandry \& Suban, 2020). Hambatan-hambatan tersebut berupa sarana dan prasarana, peserta didik yang belum terbiasa dengan pembelajaran daring. Keterbatasan lainnya dalam aksesibilitas penggunaan Internet.

Permasalahan tersebut dapat diatasi dengan membuat rancangan kegiatan belajar yang bisa menciptakan kemandirian serta dapat membuat hasil belajar siswa meningkat melalui penyusunan perangkat pembelajaran. Perangkat pembelajaran meliputi Rencana Pelaksanaan Pembelajaran (RPP), silabus, buku siswa, media pembelajaran dan model pembelajaran. 
Rencana pelaksanaan pembelajaran (RPP) adalah rancangan pembelajaran mata pelajaran per unit yang diterapkan guru dalam menerapkan di kelas. Berdasarkan RPP seorang guru harus mampu menerapkan pembelajaran secara tersusun. Keberhasilan belajar siswa untuk mencapai tujuan pembelajaranadalah hakikat penyusunan RPP. Langkah awal yang harus dimiliki oleh guru adalah kemampuan dalam membuat RPP. Penyususnan RPP adalah mengacu pada silabus. (Anggraeni \& Akbar, 2018)

Silabus merupakan penjabaran standar kompetensi dan kompetensi dasar ke dalam materi pokok pembelajaran, kegiatan pembelajaran, dan indikator pencapaian kompetensi untuk penilaian, begitu juga untuk (LKS), media pembelajaran, model pembelajaran dan perangkat pembelajaran lainnya sudah tercangkup kedalamnya (Preventif et al., 2020).

Perangkat pembelajaran merupakan pedoman atau petunjuk bagi guru dalam melaksanakan pembelajaran yang dapat disiapkan oleh guru maupun dari pihak lainnya (Nurrohman Muhammad, 2020). Perencanaan perangkat pembelajaran tetap menggunakan perangkat pembelajaran yang sudah ada disekolah, hanya saja implementasinya dalam pembelajaran yang berbeda. Dampak negatif dari pandemi Covid-19 adalah berakibat pada semua pembelajaran yang dilaksanakan di rumah (Indahningrum, 2020). Berubahnya sistem pembelajaran yang dialihkan dengan belajar di rumah jelas diperlukan penyusunan kembali perangkat pembelajaran yang sesuai dengan pembelajaran jarak jauh (Sari et al., n.d.).

Paparan di atas membuktikan bahwa perangkat pembelajaran sangat berperan penting dalam keberhasilan kegiatan belajar mengajar. Mewabahnya Covid-19 mempengaruhi hasil pembelajaran, karena belum adanya kesiapan baik dari sarana prasarananya maupun peserta didiknya. Seharusnya di era 4.0 ini khususnya pendidikan di Indonesia itu sudah bisa mengimbangi negara-negara lainnya (Indrayana \& Sadikin, 2020). Perangkat pembelajaran perlu diteliti berdasarkan latar belakang yang telah peneliti kemukakan dengan meneliti tentang "Analisis Perangkat Pembelajaran Pada Masa Pandemi Covid-19 di SMP Negeri 34 Bandar Lampung”.

\section{METODE PENELITIAN}

Deskriptif kualitatifadalah jenis penelitian yang digunakan pada penelitian ini. Pada penelitian kualitatif peneliti terjunlangsung sebagai instrumen sebagai mengumpulkan dan mengelola data dari informan terkait permasalahan dalam penelitian, partisipan sebagai sumber data terhubung secara langsung dengan instrumen penelitian karena peneliti sendiri menjadi bagian dari instrumen (Fitriyani1, 2020). Instrumen utama dalam penelitian ini peneliti sendiri yang bertugas untuk mengumpulkan data berupa perangkat pembelajaran dengan bantuan instrumen tambahan berupa observasi, wawancara, angket dan dokumentasi sebagai instrumen penunjang. Teknik pengambilan sampel yang digunakan yaitu Purposive Sampling (Rosdianto et al., 2017). Sampel dalam penelitian ini terdiri dari satu guru matematika kelas VII, waka kurikulum dan tiga peserta didik kelas VII F. Triangulasi teknik yang digunakan peneliti pada penelitian ini untuk mengecek keabsahan data.

\section{HASIL PENELITIAN DAN PEMBAHASAN}

Perangkat pembelajaran daring yang digunakan guru tidak terlepas dari persiapan yang dilakukan. Data mengenai persiapan guru dalam membuat perangkat pembelajaran daring diperoleh dengan metode wawancara. Pada tahap persiapan terlihat guru-guru telah mengikuti pelatihan guru kreatif yang diselenggarakan di sekolah sehingga guru dapat belajar menggunakan media elektronik. Pelatihan guru kreatif ini bertujuan untuk membekali guru dalam melaksanakan pembelajaran daring, sehingga guru tidak gagap teknologi dalam pelaksanaan pembelajaran daring. 
Berdasarkan hasil wawancara yang dilakukan dengan salah satu guru matematika dan waka kurikulum, dalam pembelajaran daring telah menggunakan RPP yang dibuat dengan menyesuaikan kondisi proses pembelajaran yaitu RPP daring. Selain menggunakan RPP daring, silabus digunakan juga dengan penyederhanaan beberapa komponen di dalamnya, seperti alokasi waktu yang dibuat lebih singkat dengan menyesuakan proses belajar yang dilakukan secara daring. LKS yang diguankan dalam pembelajaran daring sama hanya saja berbeda dalam hal penggunaan nya. LKS digunakan dengan cara memfoto bagian LKS yang akan di pelajarai kemudian guru akan membagikan ke grup whatsapp. Media pembelajaran yang digunakan yaitu dalam bentuk video pembelajaran yang dianggap cocok untuk pembelajaran daring dan model pembelajan yang digunakan adalah model pembelajaran ceramah dan penugasan. Model pembelajaran dilaksanakan melalui zoom dan grup whatsapp.

Analisis terhadap hasil dapat dibedakan menjadi lima yaitu, analisis terhadap silabus, RPP, LKS, media pembelajaran dan model pembelajaran. Berikut hasil pemaparan analisis terhadap kelima perangkat pembelajaran pada masa pandemi Covid-19.

\section{Rencana Pelaksanaan Pembelajaran Daring (RPP Daring)}

Analisis RPP dilakukan pada salah satu guru matematika dan waka kurikulum. RPP yang dianalisis adalah RPP daring yang digunakan pada prses pembelajaran daring. RPP yang dianalisis adalah RPP daring matematika kelas VII semester 1. Hasil analisis RPP daring di sajikan sebagai berikut:

a) Hasil Observasi

Dari hasil pengamatan peneliti, RPP yang digunakan adalah RPP daring. RPP daring dibuat dengan format 1 lembar. RPP daring dibuat dengan beberapa penyederhanaan komponen didalamnya. Sesuai dengan Surat Edaran Menteri Pendidikan dan Kebudayaan Republik Indonesia Nomor 14 Tahun 2019 tentang Penyederhanaan RPP. Komponen inti adalah tujuan pembelajaran, langkah-langkah pembelajaran, dan penilaian pembelajaran.(Sanusi, 2019)

b) Hasil Wawancara

Hasil wawancara menjelaskan bahwa guru pada pembelajaran daring sudah merancang RPP. RPP yang dirancang adalah RPP dalam bentuk 1 lembar atau disebut dengan RPP daring.

c) Hasil Angket

Dari hasil penilaian angket RPP yang digunakan dalam pembelajaran daring dalam kategori baik dan layak digunakan. Dikatakan baik karena dalam penilaian angket RPP yang digunakan pada pembelajaran daring mendapatkan hasil penilaian sebesar 75\% dengan kategori baik.

d) Hasil Dokumentasi

RPP yang digunakan pada pembelajaran daring dalam bentuk 1 lembar. Berisi tentang tujuan pembelajaran dan langkah-langkah pembelajaran serta penilaian pembelajaran. RPP dibuat dengan lebih sederhana sesuai dengan syarat penyederhanaan RPP pada pembelajaran daring.

Berdasarkan hasil observasi, wawancara, angket dan dokumentasi RPP daring dibuat dengan penyederhanaan beberapa komponen di dalamnya. Penyedehanaan tersebut sesuai dengan dengan Surat Edaran Menteri Pendidikan dan Kebudayaan Republik Indonesia Nomor 14 Tahun 2019 tentang Penyederhanaan RPP. RPP daring di buat dalam format satu lembar dan terdiri dari komponen inti. Komponen inti dalam RPP daring adalah langkah-langkah pembelajaran, dan penilaian pembelajaran. Sedangkan pada hasil penilaian angket juga menunjukan RPP dalam kategori baik. Berikut hasil penilaian angket RPP. 
Tabel 1. Hasil Penilaian Angket RPP daring

\begin{tabular}{|c|c|c|c|c|c|c|}
\hline $\begin{array}{c}\text { Jenis } \\
\text { Perangkat } \\
\text { Pembelajaran }\end{array}$ & Skala Likert & $\begin{array}{l}\text { Jawaban } \\
\text { Subjek } \\
\text { Penelitian }\end{array}$ & $\begin{array}{c}\text { Nilai } \\
\text { Butir } \\
\text { Penilaian }\end{array}$ & Hasil & Persen & Hasil \\
\hline \multirow{4}{*}{$\begin{array}{c}\text { Rencana } \\
\text { Pelaksanaan } \\
\text { Pembelajaran } \\
\text { (RPP) }\end{array}$} & 5 (Sangat Baik) & 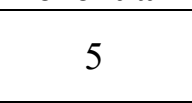 & $5 \times 5$ & 25 & $\frac{5}{37} \times 100 \%$ & $14 \%$ \\
\hline & 4 (Baik) & 26 & $26 \times 4$ & 104 & $\frac{26}{37} \times 100 \%$ & $70 \%$ \\
\hline & 3 (Cukup) & 4 & $4 \times 3$ & 12 & $\frac{4}{37} \times 100 \%$ & $11 \%$ \\
\hline & 1 (Sangat Kurang) & 0 & $0 \times 1$ & 0 & - & - \\
\hline \multicolumn{2}{|c|}{ Jumlah } & 37 & & 141 & & $100 \%$ \\
\hline \multicolumn{2}{|c|}{ Rata-rata } & \multicolumn{5}{|c|}{$\frac{\text { Skor jumlah hasil Penelitian }}{\text { Skor jumlah jawaban subjek penelitian }}=\frac{141}{37}=3.81$} \\
\hline \multicolumn{2}{|c|}{ Presentase } & \multicolumn{5}{|c|}{$\frac{\text { Skor hasil subjek penelitian }}{\text { Skor maksimal }}=\frac{141}{185} \times 100 \%=76 \%$} \\
\hline \multicolumn{2}{|c|}{ Kreteria } & \multicolumn{5}{|c|}{ Baik } \\
\hline
\end{tabular}

Berdasarkan hasil penilaian angket di atas terlihat bahwa hasil analisis RPP daring yang digunakan dalam kategori baik dan layak digunakan dengan perolehan hasil presentase $76 \%$. Hasil data dokumentasi juga menunjunjukkan bahwa RPP daring yang digunakan sudah dalam kategori baik. Berdasarkan dari pemaparan mengenai hasil analisis RPP daring yang digunakan pada pembelajaran daring terlihat bahwa RPP daring dalam kategori baik dan layak digunakan.

\section{Silabus Pembelajaran}

Hasil analisis silabus yang digunakan pada pembelajaran daring menunjukkan bahwa silabus yang digunakan dalam kategori baik. Silabus yang digunakan pada pembelajaran daring juga dilakukannya penyederhanaan beberapa komponen di dalamnya. Seperti alokasi waktu yang dibuat lebih singkat. Berikut hasil analisis silabus yang digunakan pada pembelajaran daring.

a) Hasil Observasi

Berdasarkan hasil observasi silabus digunakan dalam pembelajaran daring. Silabus pada pembelajaran daring secara umum sama dengan silabus pada pembelajaran normal, hanya saja ada penyederhanaan di beberapa komponen. Seperti alokasi waktu dan yang lainnya.

b) Hasil Waancara

Hasil wawancara menjelaskan bahwa guru menggunakan silabus pada pembelajaran daring.

Silabus digunakan sebagai acuan dalam perencanaan RPP pada pembelajaran daring.

c) Hasil Angket

Dari hasil penilaian angket terlihat bahwa silabus yang digunakan dalam pembelajaran daring mendapatkan penilaian sebesar $76 \%$ dengan kategori baik. Berdasarkan hasil tersebut maka silabus layak digunakan pada pembelajaran daring.

d) Hasil Dokumentasi

Silabus yang digunakan pada pembelajaran terdiri dari identitas sekolah, nama mata pelajaran, kelas/semester, alokasi waktu, kompetensi inti, kompetensi dasar, kegiatan pembelajaran, istrumen penilaian, dan sumber belajar silabus.

Berdasarkan hasil observasi dan wawancara silabus yang digunakan pada pembelajaran daring secara umum sama dengan silabus pada pembelajaran normal, hanya saja ada penyederhanaan di beberapa komponen. Seperti alokasi waktu dan yang lainnya. Silabus digunakan sebagai acuan dalam 
perencanaan RPP pada pembelajaran daring. Silabus yang digunakan pada pembelajaran terdiri dari identitas sekolah, nama mata pelajaran, kelas/semester, alokasi waktu, kompetensi inti, kompetensi dasar, kegiatan pembelajaran, istrumen penilaian, dan sumber belajar silabus. Penilaian angket pada silabus menunjukkan bawa silabus yang digunakan pada pembelajran daring dalam kategori baik. Berikut hasil penilaian angket silabus.

Tabel 2. Hasil Penilaian Angket Silabus Pembelajaran Daring

\begin{tabular}{|c|c|c|c|c|c|c|}
\hline $\begin{array}{c}\text { Jenis } \\
\text { Perangkat } \\
\text { Pembelajaran }\end{array}$ & Skala Likert & $\begin{array}{c}\text { Jawaban } \\
\text { Subjek } \\
\text { Penelitian } \\
\end{array}$ & $\begin{array}{c}\text { Nilai } \\
\text { Butir } \\
\text { Penilaian } \\
\end{array}$ & Hasil & Persen & Hasil \\
\hline \multirow{5}{*}{ Silabus } & 5 (Sangat Baik) & 0 & $0 \times 5$ & 0 & - & - \\
\hline & 4 (Baik) & 20 & $20 \times 4$ & 80 & $\frac{20}{26} \times 100 \%$ & $77 \%$ \\
\hline & 3 (Cukup) & 6 & $6 \times 3$ & 18 & $\frac{6}{26} \times 100 \%$ & $23 \%$ \\
\hline & 2 (Kurang) & 0 & $0 \times 2$ & 0 & - & - \\
\hline & 1 (Sangat Kurang) & 0 & $0 \times 1$ & 0 & - & - \\
\hline \multicolumn{2}{|c|}{ Jumlah } & 26 & & 98 & & $100 \%$ \\
\hline \multicolumn{2}{|c|}{ Rata-rata } & \multicolumn{5}{|c|}{$\frac{\text { Skor jumlah hasll subjek penelittan }}{\text { Skor jumlah jawaban subjek penelitian }}=\frac{98}{26}=3,76$} \\
\hline \multicolumn{2}{|c|}{ Presentase } & \multicolumn{5}{|c|}{$\frac{\text { Skor hasil subjek penelitian }}{\text { Skor maksimal }} \times 100 \%=\frac{98}{130} \times 100 \%=75 \%$} \\
\hline \multicolumn{2}{|c|}{ Kreteria } & \multicolumn{5}{|c|}{ Baik } \\
\hline
\end{tabular}

Berdasarkan hasil penilaian angket pada perangkat pembelajaran silabus terlihat bahwa silabus yang digunakan pada pembelajaran daring dalam kategori baik dengan perolehan presentase $75 \%$. Silabus yang digunakan pada pembelajaran daring sudah memenuhi standar pengembangan silabus. Berdasarkan hasil dokumentasi silabus dalam ketegori baik.

\section{Lembar Kerja Siswa}

Hasil analisis LKS yang digunakan guru sebagai salah satu sumber belajar pada pembelajran daring dalam kategori baik. LKS yang digunakan guru pada pembelajaran daring masih sama dengan LKS yang digunakan pada pembelajaran tatap muka hanya saja berbeda dalam hal penggunaannya. Berikut hasil analisis LKS yang digunakan pada pembelajaran daring.

a) Hasil Observasi

Berdasarkan dari pengamatan peneliti, LKS digunakan pada pembelajaran daring sebagai salah satu sumber belajar. LKS dipilih menjadi salah satu sumber belajar karena disesuaikan dengan pembelajaran saat ini. LKS berisikan rangkuman materi, contoh soal dan latihan soal. Untuk itu LKS dianggap cocok digunakan sebagai salah satu sumber belajar pada pembelajaran daring.

b) Hasil Wawancara

Berdasarkan hasil wawancara dalam pembelajaran daring guru menggunakan LKS sebagai salah satu sumber belajar. LKS digunakan dengan cara difoto bagian halaman yang akan dipelajari kemudian di bagikan kepada peserta didik melalui grup Whatsapp.

c) Hasil Angket

Dari hasil penilaian angket terlihat bahwa LKS yang digunakan dalam pembelajaran daring mendapat hasil penilaian $70 \%$ dengan kategori baik. Untuk itu LKS yang digunakan pada pembelajaran daring layak digunakan. 
d) Hasil Dokumentasi

LKS yang digunakan pada pembelajaran daring berisikan rangkuman materi, contoh soal dan soal-soal latihan. LKS digunakan dengan cara memfoto bagian halaman yang akan dipelajari kemudian membagikannya ke grup whatsapp.

Berdasarkan hasil observasi dan wawancara terlihat bahwa LKS digunakan sebagai salah satu sumber belajar pada pembelajaran matematika di kelas VII pada pembelajaran daring. LKS dipilih menjadi salah satu sumber belajar karena disesuaikan dengan pembelajaran saat ini. LKS berisikan rangkuman materi, contoh soal dan latihan soal. Untuk itu LKS dianggap cocok digunakan sebagai salah satu sumber belajar pada pembelajaran daring. Penggunaan LKS pada pembelajaran daring yaitu dengan cara difoto bagian halaman yang akan dipelajari kemudian di bagikan kepada peserta didik melalui grup Whatsapp. Hasil penilaian angket LKS juga membuktikan bahwa LKS yang digunakan pada pembelajaran daring dalam kategori baik. Berikut hasil penilian angket LKS.

Tabel 3. Hasil Penilaian Angket Lembar Kerja Siswa (LKS)

\begin{tabular}{|c|c|c|c|c|c|c|}
\hline $\begin{array}{c}\text { Jenis } \\
\text { Perangkat } \\
\text { Pembelajaran }\end{array}$ & Skala Likert & $\begin{array}{c}\text { Jawaban } \\
\text { Subjek } \\
\text { Penelitian }\end{array}$ & $\begin{array}{c}\text { Nilai } \\
\text { Butir } \\
\text { Penilaian }\end{array}$ & Hasil & Persen & Hasil \\
\hline \multirow{5}{*}{$\begin{array}{l}\text { Lembar Kerja } \\
\text { Siswa (LKS) }\end{array}$} & 5 (Sangat Baik) & 0 & $0 \times 5$ & 0 & - & - \\
\hline & 4 (Baik) & 11 & $11 \times 4$ & 44 & $\frac{11}{22} \times 100 \%$ & $50 \%$ \\
\hline & 3 (Cukup) & 11 & $11 \times 3$ & 33 & $\frac{11}{22} \times 100 \%$ & $50 \%$ \\
\hline & 2 (Kurang) & 0 & $0 \times 2$ & 0 & - & - \\
\hline & 1 (Sangat Kurang) & 0 & $0 \times 1$ & 0 & - & - \\
\hline \multicolumn{2}{|c|}{ Jumlah } & 22 & & 77 & & $100 \%$ \\
\hline \multicolumn{2}{|c|}{ Rata-rata } & \multicolumn{5}{|c|}{$\frac{\text { Skor jumlah hasil subjek penelitian }}{\text { Skor jumlah jawabun subjek penelitian }}=\frac{77}{22}=3,5$} \\
\hline \multicolumn{2}{|c|}{ Presentase } & \multicolumn{5}{|c|}{$\frac{\text { Skor hasil subjek penelitian }}{\text { Skor maksimal }} \times 100 \%=\frac{77}{110} \times 100 \%=70 \%$} \\
\hline \multicolumn{2}{|c|}{ Kreteria } & \multicolumn{5}{|c|}{ Baik } \\
\hline
\end{tabular}

Berdasarkan hasil penilian angket di atas, terlihat bahwa LKS yang digunakan guru sebagai salah satu sumber belajar pada pembelajaran daring dalam ketegori baik yaitu dengan perolehan hasil $70 \%$. LKS dianalisis berdasarkan indikator kesesuaian materi dengan kompetensi dasar, keruntutan penyajian materi, kesesuaian dengan kemampuan siswa, ketepatan penggunaan bahasa dan kalimat, dan ketepatan pertanyaan dan sumber belajar. Hasil data dokumetasi juga menjelaskan bahwa LKS yang digunakan pada pembelajaran daring berisikan rangkuman materi, contoh soal dan latihan soal yang dapat langsung dikerjakan oleh peserta didik.

\section{Media Pembelajaran}

Hasil analisis media pembelajaran yang digunakan pada pembelajaran daring juga menunjukkan dalam kategori baik dan layak digunakan. Media pembelajaran yang digunakan pada pembelajaran daring berupa video pembelajaran penjelasan materi pelajaran, meliputi tujuan pembelajaran, penjelasan materi, contoh soal dan latihan soal. Berikut hasil analisis media pembelajaran yang dugunakan pada pembelajaran daring (Herliandry et al., 2020). 
a) Hasil Observasi

Berdasarkan hasil observasi media pembelajan yang digunakan pada pembelajaran daring adalah media yang dianggap cocok dan bisa digunakan secara online. Dalam pembelajaran daring tidak dapat menggunakan media pembelajaran dalam bentuk kongkret dan melibatkan peserta didik untuk turut aktif didalamnya. Media yang diguanakan dalam pembelajaran daring adalah video pembelajaran.

b) Hasil Wawancara

Dari hasil wawancara dalam pembelajaran daring guru menggunakan media pembelajaran. Media pembelajaran yang digunakan dalam bentuk video pembelajaran. Video pembelajaran biasanya dibuat sendiri oleh guru, terkadang juga mencari video yang sesuai dari Youtube.

c) Hasil Angket

Dari hasil penilaian angket media pembelajaran yang digunakan dalam pembelajaran daring sudah dalam kategori baik dengan mendapatkan penilaian sebesar $73 \%$. Dikatakan baik media pembelajaran yang digunakan telah mencangkup penyusun komponen media pembelajaran yang baik.

d) Hasil Dokumentasi

Video pembelajaran adalah media pembelajaran yang digunakan dalam pembelajaran daring. Video pembelajaran memuat tujuan pembelajaran, penjabaran materi, contoh soal dan latihan soal. Video pembelajaran yang digunakan kadang dibuat sendiri oleh guru, kadang juga mencari video yang sesuai di Youtube yang kemudian dibagikan kepada peserta didik.

Berdasarkan hasil observasi dan wawancara media pembelajaran yang digunakan pada pembelajaran daring adalah video pembelajaran. Video pembelajaran biasanya dibuat sendiri oleh guru, terkadang juga mencari video yang sesuai dari Youtube. Video pembelajaran berisikan tujuan pembelajaran, pemjelasan materi, penjabaran contoh soal dan latihan soal. Hasil angket juga menunjukkan bahwa media pembelajran yang digunakan pada pembelajaran daring dalam kategori baik. Berikut hasil penilaian angket media pembelajaran.

Tabel 4. Penilaian Anget Media Pembelajaran

\begin{tabular}{|c|c|c|c|c|c|c|}
\hline $\begin{array}{c}\text { Jenis } \\
\text { Perangkat } \\
\text { Pembelajaran }\end{array}$ & Skala Likert & $\begin{array}{l}\text { Jawaban } \\
\text { Subjek } \\
\text { Penelitian } \\
\end{array}$ & $\begin{array}{c}\text { Nilai } \\
\text { Butir } \\
\text { Penilaian }\end{array}$ & Hasil & Persen & Hasil \\
\hline \multirow{5}{*}{$\begin{array}{c}\text { Media } \\
\text { Pembelajaran }\end{array}$} & 5 (Sangat Baik) & 0 & $0 \times 5$ & 0 & - & - \\
\hline & 4 (Baik) & 9 & $9 \times 4$ & 36 & $\frac{9}{17} \times 100 \%$ & $52 \%$ \\
\hline & 3 (Cukup) & 8 & $8 \times 3$ & 24 & $\frac{8}{17} \times 100 \%$ & $48 \%$ \\
\hline & 2 (Kurang) & 0 & $0 \times 2$ & 0 & - & - \\
\hline & 1 (Sangat Kurang) & 0 & $0 \times 1$ & 0 & - & - \\
\hline \multicolumn{2}{|c|}{ Jumlah } & 17 & & 60 & & $100 \%$ \\
\hline \multicolumn{2}{|c|}{ Rata-rata } & \multicolumn{5}{|c|}{$\frac{\text { Skor jumlah hasil subjek penelitian }}{\text { Skor jumlah jowaban subjek peneitition }}=\frac{60}{17}=3,52$} \\
\hline \multicolumn{2}{|c|}{ Presentase } & \multicolumn{5}{|c|}{$\frac{\text { Skor hasil subjek penelitian }}{\text { Skor maksimal }} \times 100 \%=\frac{60}{85} \times 100 \%=75 \%$} \\
\hline \multicolumn{2}{|c|}{ Kreteria } & \multicolumn{5}{|c|}{ Baik } \\
\hline
\end{tabular}


Berdasarkan hasil penilaian angket di atas menunjukkan bahwa media pembelajaran yang digunakan pada pembelajaran daring dalam ketegori baik dengan perolehan hasil sebesar $75 \%$. Media pebelajaran dianalisis berdasarkan indikator tampilan media, soal dan jawaban soal, kejelasan tujuan pembelajaran, ketepatan materi yang disajikan dalam media pembelajaran dan kesesuaian permasalahan dalam media pembelajaran. Hasil data dokumentasi juga menunjukkan bahwa media pembelajaran berisikan tujuan pembelajaran, penjelasan materi, contoh soal dan latihan soal.

\section{Model Pembelajaran}

Hasil analisis model pembelajaran yang digunakan pada pembelajaran daring menunjukkan dalam kategori baik dan layak digunakan. Model pembelajaran yang digunakan adalah model pembelajaran ceramah dan penugasan. Berikut hasil analisis model pembelajaran yang digunakan pada pembelajaran daring.

a) Hasil Observasi

Dari hasil observasi dalam pembelajaran daring menggunakan model pembelajaran ceramah dan penugasan. Model ceramah diguanakan untuk menjelaskan materi kepada peserta didik melalui pertemuan zoom dan dianggap cocok pada pembelajaran daring. Model penugasan digunakan untuk mengukur kemampuan peserta didik secara kognitif. Penugasan dilakukan untuk membuat peserta didik lebih banyak latihan soal.

b) Hasil Wawancara

Berdasarkan hasil wawancara dalam pembelajaran jarak jauh guru memilih model pembelajaran ceramah dan penugasan. Model pembelajaran ceramah diterapkan pada saat pertemuan melalui zoom dan penugasan dilakuakn untuk mengukur kemampuan peserta didik.

c) Hasil Angket

Dari hasil penilaian angket model pembelajaran yang digunakan dalam pembelajaran daring sudah dalam kategori baik dengan mendapat penilaian sebesar $70 \%$. Penilaian angket model pembelajaran dialakukan dengan memperhatikan komponen-komponen penyusun model pembelajaran yang baik.

d) Hasil Dokumentasi

Model pembelajaran daring adalah model pembelajaran ceramah dan penugasan. Model ceramah berisikan tentang guru yang menjelaskan materi melalui pertemuan zoom dan penugasan berisikan sekumpulan soal baik itu pilihan ganda maupun dalam bentuk essai. Penugasan dilakukan untuk mengukur kemampuan kognitif peserta didik. Tugas biasanya dikirimkan ke elearning sekolah.

Berdasarkan hasil observasi dan wawancara terlihat bahwa model pembelajran yang digunakan pada pembelajran daring adalah model pembelajaran ceramah dan penugasan. Model pembelajaran ceramah dilakukan pada saat pertemuan melalui zoom dan penugasan dilakukan untuk mengukur kemampuan peserta didik. Tugas biasanya dikirimkan melalui Whatsapp ataupun E-learning sekolah.hasil penilaian angket juga menunjukkan bahwa model pembelajaran dalam ketegori baik berikut hasil penilian angket model pembelajaran. 
Tabel 5. Hasil Penilaian Angket Model Pembelajaran

\begin{tabular}{|c|c|c|c|c|c|c|}
\hline $\begin{array}{c}\text { Jenis } \\
\text { Perangkat } \\
\text { Pembelajaran }\end{array}$ & Skala Likert & $\begin{array}{c}\text { Jawaban } \\
\text { Subjek } \\
\text { Penelitian }\end{array}$ & $\begin{array}{c}\text { Nilai } \\
\text { Butir } \\
\text { Penilaian }\end{array}$ & Hasil & Persen & Hasil \\
\hline \multirow{5}{*}{$\begin{array}{c}\text { Model } \\
\text { Pembelajaran }\end{array}$} & 5 (Sangat Baik) & 0 & $0 \times 5$ & - & - & - \\
\hline & 4 (Baik) & 8 & $8 \times 4$ & 32 & $\frac{8}{16} \times 100 \%$ & $50 \%$ \\
\hline & 3 (Cukup) & 8 & $8 \times 3$ & 24 & $\frac{8}{16} \times 100 \%$ & $50 \%$ \\
\hline & 2 (Kurang) & 0 & $0 \times 2$ & 0 & - & - \\
\hline & 1 (Sangat Kurang) & 0 & $0 \times 1$ & 0 & - & - \\
\hline \multicolumn{2}{|c|}{ Jumlah } & 16 & & 56 & & $100 \%$ \\
\hline \multicolumn{2}{|c|}{ Rata-rata } & \multicolumn{5}{|c|}{$\begin{array}{l}\text { Skor jumlah hasil subjek penelitian } \\
\text { Skor jum lah jawaban subjek peneitition }\end{array}$} \\
\hline \multicolumn{2}{|c|}{ Presentase } & \multicolumn{5}{|c|}{$\frac{\text { Skor hasil subjek penelitian }}{\text { Skor maksimal }} \times 100 \%=\frac{56}{80} \times 100 \%=70 \%$} \\
\hline \multicolumn{2}{|c|}{ Kreteria } & \multicolumn{5}{|c|}{$\begin{array}{ll}\text { Baik } \\
\end{array}$} \\
\hline
\end{tabular}

Berdasarkan hasil penilaian angket di atas menunjukkan bahwa model pembelajaran yang digunakan pada pembelajaran daring dalam kategori baik yaitu dengan perolehan hasil sebesar $70 \%$. Model pembelajaran dianalisis berdasarkan indikator kejelasan petunjuk penggunaan, kesesuaian model pembelajara, kesesuaian permasalahan dengan model pembelajaran dan kesesuaian pemilihan model pembelajaran. Hasil data dokumentasi juga menunjukkan bahwa model pembelajran yang digunakan pada pembelajaran daring adalah model pembelajaran ceramah dan penugasan.

\section{Persamaan dan Perbedaan Perangkat Pembelajaran Pada Masa Pandemi dan Sebelum Pandemi Covid-19}

Persamaan perangkat pembelajaran yang digunakan pada saat pandemi dan juga sebelum pandemi adalah dalam pembelajaran daring maupun tatap muka masih sama menggunakan perangkat pembelajaran seperti silabus, RPP, LKS, media pembelajaran, dan model pembelajaran. Guru menggunakan dan juga mempersiapkan perangkat pembelajaran pada pembelajaran daring dengan menyesuaikan keadaan dan situasi saat ini.

Perbedaan perangkat pembelajaran yang digunakan pada saat pandemi dan sebelum pandemi adalah dalam hal penerapan, penggunaan dan juga penyederhanaan beberapa jenis perangkat pembelajaran yang digunakan. Beberapa jenis perangkat pembelajaran seberti silabus dan juga RPP di buat dengan menyederhanakan beberapa komponen di dalamnya, seperti dibuat lebih singkat dalam hal alokasi waktu pada pembelajaran daring (Sanusi, 2019). Penggunaan LKS juga berbeda dengan pembelajaran tatap muka, LKS digunakan pada pembelajaran daring dengan cara di foto pada halaman yang akan dipelajari kemudian di bagikan ke grup kelas. Penggunaan media pembelajaran juga berbeda dengan pembelajaran tatap muka, pemilihan media pembelajaran disesuaikan dengan pembelajaran daring, media pembelajaran yang dipilih adalah video pembelajaran. Penggunaan model pembelajaran juga berbeda dengan pembelajaran langsung, pada langsung belajar guru bisa menggunakan model pembelajaran yang peserta didik dapat ikut aktif di dalam pembelajaran, seperti model pembelajaran kooperatif. (Jayul \& Irwanto, 2020). Namun, pada pembelajaran daring guru harus memilih model pembelajaran yang sesuai dengan pembelajaran daring. Model pembelajaran daring yang dipilih adalah model pembelajaran ceramah dan penugasan. 


\section{KESIMPULAN}

Perangkat pembelajaran yang digunakan pada pembelajaran daring di SMP Negeri 34 Bandar Lampung sudah dalam kategori baik. Silabus digunakan pada pembelajaran daring sebagai pedoman utama untuk penyusunan perangkat pembelajaran yang lain. Guru telah melakukan perencanaan pembelajaran dengan membuat RPP daring, menggunakan LKS sebagai salah satu sumber belajar. mempersiapkan media pembelajaran berupa video penjelasan materi, dan menggunakan model pembelajaran ceramah dan penugasan pada pembelajaran daring.

Penilaian angket menunjukkan bahwa perangkat pembelajaran yang digunakan di sekolah sudah dalam kategori baik hal itu dibuktikan dengan perolehan penilaian silabus sebesar $76 \%$ dengan kategori baik, perolehan penilaian RPP sebesar 75\% dengan kategori baik, LKS dengan perolahan penilaian $71.5 \%$ dengan kategori baik, media pembelajaran dengan perolehan penilaian $73 \%$ dengan kategori baik dan model pembelajaran dengan perolehan penilaian $70.5 \%$ dengan ketegori baik. Perbedaan perangkat pembelajaran yang digunakan pada saat pandemi dan sebelum pandemi adalah dalam hal penerapan, penggunaan dan juga penyederhanaan beberapa jenis perangkat pembelajaran yang digunakan.

\section{REFERENCES}

Anggraeni, P., \& Akbar, A. (2018). Kesesuaian Rencana Pelaksanaan Pembelajaran Dan Proses Pembelajaran. Jurnal Pesona Dasar, 6(2), 55-65. https://doi.org/10.24815/pear.v6i2.12197

Darmalaksana, W., Hambali, R. Y. A., Masrur, A., \& Muhlas. (2020). Analisis Pembelajaran Online Masa WFH Pandemic Covid-19 sebagai Tantangan Pemimpin Digital Abad 21. Karya Tulis Ilmiah (KTI) Masa Work From Home (WFH) Covid-19 UIN Sunan Gunung Djati Bandung Tahun 2020, 1(1), 1-12.

Firman. (2020). Dampak Covid-19 terhadap Pembelajaran di Perguruan Tinggi. Bioma, 2(1), 14-20.

Fitriyani1, Y. (2020). Motivasi Belajar Mahasiswa Pada Pembelajaran Daring Selama Pandemik Covid-19. Jurnal Hasil Penelitian Dan Kajian Kepustakaan Di Bidang Pendidikan, Pengajaran Dan Pembelajaran, 6(2), 165-175.

Herliandry, L. D., Nurhasanah, Suban, M. E., \& Heru, K. (2020). Transformasi Media Pembelajaran Pada Masa Pandemi Covid-19. Jurnal Teknologi Pendidikan, 22(1), 65-70. https://doi.org/https://doi.org/10. 21009/jtp.v22i1.15286

Herliandry, L. D., \& Suban, M. E. (2020). Pembelajaran Pada Masa Pandemi Covid-19. Teknologi Pendidikan, 22(1), 65-70.

Indahningrum, R. putri. (2020). IMPLEMENTASI PERANGKAT PEMBELAJARAN BAHASA INDONESIA KELAS X AKOMODASI PERHOTELAN PROGRAM INKLUSI DI SMKN 2 MALANG PADA MASA PANDEMI COVID-19. 2507(1), 1-9.

Indrayana, B., \& Sadikin, A. (2020). Penerapan E-Learning Di Era Revolusi Industri 4.0 Untuk Menekan Penyebaran Covid-19. Indonesian Journal of Sport Science and Coaching, 2(1), 4655. https://doi.org/10.22437/ijssc.v2i1.9847

Jauhari, M. N., Sambira, \& Zakiah, Z. (2020). Dampak Pandemi Covid-19 Terhapad Pelaksanaan Pembelajaran Penjas Adaptif Di Sekolah Luar Biasa. Journal STAND: Sports and Development, $1(1), 63-70$.

Jayul, A., \& Irwanto, E. (2020). Model Pembelajaran Daring Sebagai Alternatif Proses Kegiatan Belajar Pendidikan Jasmani di Tengah Pandemi Covid-19. Jurnal Pendidikan Kesehatan Rekreasi, 6(2), 190-199.

Preventif, P., Dalam, P., Penyebaran, P., Syaykh, S., Di, A.-Z., Kontribusinya, A., Masyarakat, T., Prawoto, I., Rohmah, S. N., Sunarya, F. R., Tindakan, T., Kekuasaan, D., Weber, M., Mushodiq, M. A., Imron, A., Aji, A. M., Sosial, J., Syar-i, B., \& Pembelajaran, P. (2020). 
Dampak Covid-19 pada Pendidikan di Indonesia. Jurnal Sosial \& Budaya Syar-i FSH UIN Syarif Hidayatullah Jakarta, 7(5), 396. https://doi.org/10.15408/sjsbs.v7i5.15314

Rosdianto, H., Murdani, E., Rosdianto, H., \& Murdani, E. (2017). IMPLEMENTASI MODEL PEMBELAJARAN POE (PREDICT OBSERVE EXPLAIN) UNTUK MENINGKATKAN PEMAHAMAN KONSEP SISWA PADA MATERI HUKUM NEWTON. Jurnal Pendidikan Fisika, 6(1), 55-57.

Rusdiana, A., Sulhan, M., Arifin, I. Z., \& Kamludin, U. A. (2020). Penerapan Model POE2WE Berbasis Blended Learning Google Classroom Pada Pembelajaran Masa WFH Pandemic Covid19. Karya Tulis Ilmiah UIN Bandung 2020, 1-10.

Sabaruddin, Marzuki, \& Khairunnisak. (2020). Pandemic Covid-19: The Opportunities and Challenges to Using ICT in Mathematics Learning. IJEBD International Journal Of Entrepreneurship And Business Development EISSN 2597-4785 PISSN 2597-4750, 3(4), 409-414.

Sadikin, A., Hamidah, A., Pinang, K., Jl, M., Ma, J., Km, B., Indah, M., Jaluko, K., Kode, K. M., \& Indonesia, P. (2020). Pembelajaran Daring di Tengah Wabah Covid-19 ( Online Learning in the Middle of the Covid-19 Pandemic ). Jurnal Ilmiah Pendidikan Biologi, 6(1), 214-224.

Sanusi. (2019). Kudaile 05 Dan 06 , Kecamatan Slawi, Kabupaten Tegal Pada Masa Pandemi Covid19 Melalui Workshop Penulisan Rencana Pelaksanaan Pembelajaran Satu. 14, 11-14.

Sari, W., Rifki, A. M., \& Karmila, M. (n.d.). ANALISIS KEBIJAKAN PENDIDIKAN TERKAIT IMPLEMENTASI PEMBELAJARAN JARAK JAUH PADA MASA DARURAT COVID 19. 1.

Wiryanto. (2020). Proses Pembelajaran Matematika di Sekolah Dasar di Tengah Pandemi COVID-19. Jurnal Review Pendidikan Dasar: Jurnal Kajian Pendidikan Dan Hasil Penelitian, 6(2). http://journal.unesa.ac.id/index.php/PD

Sari, Widya, Andi Muhammad Rifki, And Mila Karmila. "Analisis Kebijakan Pendidikan Terkait Implementasi Pembelajaran Jarak Jauh Pada Masa Darurat Covid 19," No. 1 (N.D.).

Wahyudin Darmalaksana et al., "Analisis Pembelajaran Online Masa WFH Pandemic Covid-19 Sebagai Tantangan Pemimpin Digital Abad 21," Karya Tulis Ilmiah (KTI) Masa Work From Home (WFH) Covid-19 UIN Sunan Gunung Djati Bandung Tahun 2020 1, no. 1 (2020): 15.

Wiryanto. "Proses Pembelajaran Matematika Di Sekolah Dasar Di Tengah Pandemi COVID-19." Jurnal Review Pendidikan Dasar: Jurnal Kajian Pendidikan dan Hasil Penelitian 6, no. 2 (2020). http://journal.unesa.ac.id/index.php/PD 